Correspondence

Rosa Margesin

rosa.margesin@uibk.ac.at

\section{Mrakiella cryoconiti gen. nov., sp. nov., a psychrophilic, anamorphic, basidiomycetous yeast from alpine and arctic habitats}

\author{
Rosa Margesin ${ }^{1}$ and Jack W. Fell ${ }^{2}$ \\ ${ }^{1}$ Institute of Microbiology, University of Innsbruck, Technikerstrasse 25, 6020 Innsbruck, Austria \\ ${ }^{2}$ Rosenstiel School of Marine and Atmospheric Science, University of Miami, Key Biscayne, FL \\ 33149, USA
}

\begin{abstract}
A novel psychrophilic basidiomycetous species is described in a new anamorphic genus as Mrakiella cryoconiti gen. nov., sp. nov.; the type strain of Mrakiella cryoconiti is strain $\mathrm{A} 15^{\top}$ $\left(=\right.$ CBS $10834^{\top}=$ DSM $\left.21094^{\top}\right)$. Two representatives were isolated from alpine glacier cryoconite and from northern Siberian sediment. Physiological and biochemical properties are similar to characteristics shared by members of the genus Mrakia, although sexual reproduction is absent. Mrakiella cryoconiti strains are psychrophilic and produce cold-active pectate lyase. Sequence analyses of the ITS and 26S rRNA D1/D2 regions indicated that these strains represent a distinct taxon within the Mrakia clade of the order Cystofilobasidiales, class Tremellomycetes and phylum Basidiomycota. On the basis of phenotypic and genotypic characteristics, Cryptococcus aquaticus (a member of the Mrakia clade) is transferred to the newly described genus as Mrakiella aquatica comb. nov.
\end{abstract}

\section{INTRODUCTION}

The order Cystofilobasidiales (Fell et al., 1999) includes teleomorph and anamorph genera. Psychrophily, i.e. the ability to grow and reproduce well at temperatures around $0{ }^{\circ} \mathrm{C}$ (Morita, 1975; Margesin et al., 2008), is a typical feature of the teliospore-producing genus Mrakia; the lowest growth temperature for Mrakia strains was reported to be $-12{ }^{\circ} \mathrm{C}$ (Panikov \& Sizova, 2007). Members of this genus have been isolated from numerous low-temperature environments in various regions, such as forest substrates in European Russia, glacier-preserved fossil lichens in Greenland, Antarctic soil or snow, glacial meltwater rivers in Patagonia, Argentina, and alpine Italian subglacial sediments, ice and meltwater, but also from frozen fish in Japan and frozen yoghurt in Brazil (Fell \& Statzell-Tallman, 1998; Moreira et al., 2001; Bab'eva et al., 2002; Xin \& Zhou, 2007; Turchetti et al., 2008). Some strains related to the species Mrakia frigida produce cold-active pectinolytic enzymes (Barnett et al., 2000; Nakagawa et al., 2004). These enzymes could be useful for a wide range of applications, such as the food industry for juice clarification below $5{ }^{\circ} \mathrm{C}$ or low-temperature pre-treatment of wastewater contain-

Abbreviations: DBB, diazonium blue B; ITS, internal transcribed spacer; LSU, large subunit.

The GenBank/EMBL/DDBJ accession numbers for the ITS domain and LSU rRNA gene D1/D2 domain sequences of strains A15 ${ }^{\top}$ and $A G 25$ are AJ866976 and AJ866977 (ITS) and AJ866978 and AJ866979 (D1/D2), respectively. ing pectic substances. Two cold-active pectate-lyaseproducing strains (Margesin et al., 2005) were previously assigned to Mrakia frigida on the basis of internal transcribed spacer (ITS) and large-subunit (LSU) rRNA gene sequences. However, detailed investigation of the strains demonstrated the absence of teliospore production, which is characteristic of the genus Mrakia. In addition, ITS and LSU rRNA gene D1/D2 sequences indicate that these strains belong to a hitherto unknown genus and species, for which the name Mrakiella cryoconiti gen. nov., sp. nov. is proposed.

\section{METHODS}

Sample collection and isolation. Yeast strain $\mathrm{A} 15^{\mathrm{T}}$ was isolated from alpine glacier cryoconite collected from the Stubaier glacier near Innsbruck in Tyrol, Austria (altitude $2900 \mathrm{~m}$ above sea level) (Margesin et al., 2002). Strain AG25 originated from a sediment sample containing mud, spring water and moss, which was collected in the Gyda peninsula in northern Siberia (Gounot, 2001). Yeasts were maintained on R2A agar (Difco) plates; long-term storage was performed in $10 \%(\mathrm{w} / \mathrm{v})$ skimmed milk at $-80{ }^{\circ} \mathrm{C}$.

Physiological and biochemical characterization. Morphological, physiological and biochemical properties were determined according to Kurtzman \& Fell (1998) and Barnett et al. (2000). Induction of the sexual stage was tested by incubating single or mixed cultures of the each of the two strains on cornmeal agar (CMA), Sabouraud glucose agar (SabG) or R2A agar (Difco) at 1 and $10{ }^{\circ} \mathrm{C}$ for 2 months. Assimilation of carbon and nitrogen compounds and growth requirements were tested at $10-15{ }^{\circ} \mathrm{C}$. The effect of temperature 
was examined at $1-30{ }^{\circ} \mathrm{C}\left(5{ }^{\circ} \mathrm{C}\right.$ intervals $)$ in liquid culture and on agar plates; pectate lyase production was determined as described previously (Margesin et al., 2005).

Phylogenetic analysis. Phylogenetic analysis was done by sequencing the ITS region and the $5^{\prime}$ end of the LSU rRNA gene, including the variable domain D1 and D2. For DNA isolation, cells were harvested from 5-day-old subcultures and lyophilized. DNA was isolated by the CTAB (hexadecyltrimethylammonium bromide) method (O'Donnell et al., 1997). Primers used for the two distinct PCRs and sequencing of the two fragments were ITS5 (5'-GGAAGTAAAAGTCGTAACAAGG-3'), IT2 (5'-CCTCCGCTTATTGATATGCTTAAG-3'), F63 (5'-GCATATCAATAAGCGGAGGAAAAG$\left.3^{\prime}\right)$ and LR3 (5' ${ }^{\prime}$-TCCTCCGCTTATTGATATGC- $\left.3^{\prime}\right)$. Conditions for the two PCRs were identical. DNA was amplified through 35 cycles of $30 \mathrm{~s}$ at $92{ }^{\circ} \mathrm{C}, 30 \mathrm{~s}$ at $52{ }^{\circ} \mathrm{C}$ and $1 \mathrm{~min}$ at $72{ }^{\circ} \mathrm{C}$. DNA sequencing was performed with primers ITS5 and IT2 using a BeckmanCoulter CEQ Dye Terminator Cycle Sequencing Quick Start kit. Heuristic maximum-parsimony analysis was employed (100 rounds of heuristic search with TBR branch swapping, starting from trees obtained by random addition of sequences, multrees option on, deepest descent option off) and was validated using 1000 rounds of bootstrap analysis (Felsenstein, 1985). Maximum-parsimony, neighbour-joining and bootstrap calculations used the PAUP* software (Swofford, 2001).

\section{RESULTS AND DISCUSSION}

\section{Phenotypic properties of strains}

Two representatives of Mrakiella cryoconiti gen. nov., sp. nov. were isolated from remote geographical, alpine and arctic locations (European alpine glacier, northern Siberia). Their physiological and biochemical properties were almost identical. The strains utilized D-glucuronate, myoinositol and nitrate, produced starch-like compounds and lacked the capacity to utilize aromatic compounds (phenol), which are characteristics typical of the Cystofilobasidiales (Fell et al., 1999; Sampaio, 2004). The strains also shared a number of properties with representatives of the teliospore-producing genus Mrakia, such as psychrophilic growth (maximum growth temperature $20{ }^{\circ} \mathrm{C}$ ) and positive diazonium blue $\mathrm{B}$ (DBB) and urease reactions (Fell \& Statzell-Tallman, 1998). However, attempts to induce the sexual stage were always negative. Asexual reproduction occurred by polar budding. Differentiating phenotypic characteristics of species of the genera Mrakiella and Mrakia are shown in Table 1.

Table 1. Differentiating phenotypic characteristics of species of the genera Mrakiella and Mrakia

Data were taken from Jones \& Sloof (1966), Kurtzman \& Fell (1998), Bab'eva et al. (2002), Xin \& Zhou (2007), the CBS Data Base (http:// www.cbs.knaw.nl/) and this study. All strains are positive for the following features: aerobic growth, asexual reproduction by polar budding, DBB reaction, formation of extracellular amyloid compounds, urea hydrolysis and assimilation of D-glucose, galactose, trehalose, D-xylose, L-arabinose, D-mannitol, D-gluconate, salicin and nitrate. All strains are negative for assimilation of erythritol. +, Positive; -, negative; v, variable; w, weak; d, delayed; ND, no data available; $T_{\max }$, maximum growth temperature.

\begin{tabular}{|c|c|c|c|c|c|c|}
\hline Characteristic & $\begin{array}{l}\text { Mrakiella } \\
\text { cryoconiti }\end{array}$ & $\begin{array}{c}\text { Mrakiella } \\
\text { aquatica }\end{array}$ & Mrakia curviuscula & $\begin{array}{c}\text { Mrakia frigida (type } \\
\text { species) }\end{array}$ & $\begin{array}{c}\text { Mrakia } \\
\text { gelida }\end{array}$ & $\begin{array}{c}\text { Mrakia } \\
\text { psychrophila }\end{array}$ \\
\hline$T_{\max }\left({ }^{\circ} \mathrm{C}\right)$ & 20 & $20^{a_{*}}, 21^{b}$ & 25 & 17 & 17 & 18 \\
\hline Growth at $25{ }^{\circ} \mathrm{C}$ & - & - & + & - & - & - \\
\hline Teliospores & - & - & $+(?)$ & + & + & + \\
\hline Glucose fermentation & - & $--^{a b}, \mathrm{w}^{c}$ & - & + & + & + \\
\hline \multicolumn{7}{|l|}{ Growth on (assimilation of): } \\
\hline Raffinose & + & + & - & + & + & + \\
\hline Lactose & + & + & + & $\mathrm{v}$ & - & + \\
\hline Maltose & + & + & + & - & + & + \\
\hline Melezitose & + & + & + & - & + & + \\
\hline Soluble starch & + & + & $\mathrm{v}$ & - & + & + \\
\hline D-Ribose & + & $\mathrm{w}, \mathrm{d},-$ & $\mathrm{w}$ & - & $\mathrm{v}$ & + \\
\hline Glycerol & + & $\mathrm{d}$ & - & $\mathrm{v}$ & - & + \\
\hline Inositol & + & - & - & $\mathrm{v}$ & $\mathrm{v}$ & + \\
\hline Methanol & - & - & - & - & - & + \\
\hline Citrate & - & + & + & $\mathrm{v}$ & $\mathrm{v}$ & - \\
\hline $\begin{array}{l}\text { Methyl } \alpha \text {-D-glucopyrano- } \\
\text { side }\end{array}$ & - & - & - & - & $\mathrm{v}$ & + \\
\hline D-Glucosamine & $\mathrm{v}$ & - & + & - & + & + \\
\hline Vitamin-free medium & - & - & - & - & - & + \\
\hline $50 \%$ Glucose & + & - & $\mathrm{w} /-$ & - & - & + \\
\hline Splitting of arbutin & + & + & ND & + & + & - \\
\hline
\end{tabular}

${ }^{*}$ Data obtained from: $a$, this study; $b$, CBS Data Base; $c$, Jones \& Sloof (1966). 


\section{Phylogenetic placement}

Sequence analysis of the D1/D2 domain of the LSU rRNA gene of representative strains of species in Cystofilobasidiales (Fig. 1) demonstrates seven major groups. (i) The genus Mrakia (Mrakia gelida, Mrakia frigida and Mrakia psychrophila) is in a strongly supported $(100 \%)$ clade with strains $\mathrm{A} 15^{\mathrm{T}}$ and AG25 and the type strain of Cryptococcus aquaticus (CBS $5443^{\mathrm{T}}$ ). As discussed later, the lack of bootstrap support for the Mrakiella clade may be due to the genetic variability within and between species. (ii) The anamorphic genera Tausonia and Guehomyces are closely related. The major differences exhibited by Tausonia are the formation of incomplete clamp connections and chlamydospores. (iii) The anamorphic ballistoconidia-forming genus Udeniomyces is represented by the type species Udeniomyces pyricola and two additional species. (iv) Udeniomyces pannonicus is closely related to Itersonilia perplexans, with significant differences exhibited by I. perplexans, with the formation of pseudoclamps and appressoria. (v) Mrakia curviuscula, which inhabits grasslands of eastern Russia (Bab'eva et al., 2002), has an identical D1/D2 sequence to Cryptococcus huempii. The latter species was isolated from an evergreen forest in Chile (Ramírez \& González, 1984). Mrakia curviuscula differs from other Mrakia species in several characteristics, including environmental habitat and $T_{\max }$ of $25{ }^{\circ} \mathrm{C}$ (Bab'eva et al., 2002). The other members of the genus have a $T_{\max }$ of $20{ }^{\circ} \mathrm{C}$ or less and they are generally isolated from low-temperature, ice-associated environments. Mrakia curviuscula is reported to produce a sexual, teliosporic state; however, the photographs presented by Bab'eva et al. (2002) suggest large cells rather than the typical Mrakia-type of teliospores. Our limited investigations of the species have not confirmed the presence of a sexual state in either Mrakia curviuscula or Cryptococcus huempii. Consequently, Mrakia curviuscula may represent a synonym of the anamorphic species Cryptococcus huempii and a member of a genus that is distinct from Mrakia and Mrakiella. (vi) Cystofilobasidium is a teleomorphic and teliosporic genus. An incomplete sexual cycle for Cryptococcus macerans was reported by Rodrigues de Miranda (1984), which indicates that additional study will result in a formal description of the species as a member of Cystofilobasidium. (vii) The teleomorphic genus Xanthophyllomyces is commercially important due to the production of astaxanthin, which is a dietary pigment source for pen-raised salmon and shrimp (Johnson, 2003). As indicated by the representatives included in Fig. 1, there is considerable genetic variability between the strains, including the anamorphic state Phaffia rhodozyma (Fell et al., 2007; Weber et al., 2008).

Research in low-temperature environments has resulted in numerous reports of Mrakia in snow and soils. These strains are often identified as Mrakia gelida or Mrakia frigida, as the characterizations are by phenotypic or smallsubunit or D1/D2 LSU rRNA gene sequence analyses. Because of the similarity in these characteristics, species separations are not successful. In contrast, ITS analysis (Diaz \& Fell, 2000) provides the ability to define species and illustrate within-species variability. Research in polar and other cold environments has demonstrated the widespread occurrence of members of the Mrakia clade. Many of the strains from these ecological studies were sequenced and deposited for public use. Our analysis of ITS GenBank data (Fig. 2) should provide a guide for the phylogenetic placement of strains for on-going and future studies. The synonyms of Mrakia frigida and Mrakia gelida are included in this analysis to expand the synopsis. A major source of variability was provided by an unpublished doctoral dissertation of polar yeasts by Thomas-Hall

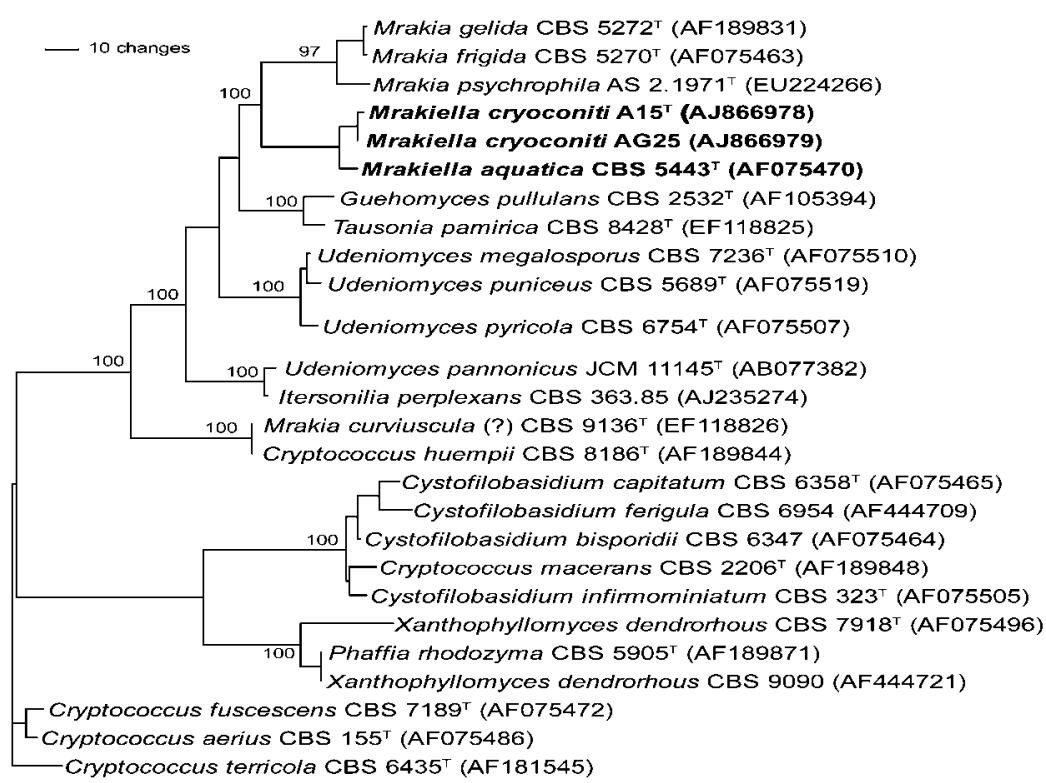

Fig. 1. Maximum-parsimony analysis (PAUP 4.0b10) of LSU rRNA gene D1/D2 domain sequences of representative strains of species in the Cystofilobasidiales. Cryptococcus fuscescens CBS $7189^{\top}$, Cryptococcus aerius CBS $155^{\top}$ and Cryptococcus terricola CBS $6435^{\top}$ represent an outgroup. Numbers at branch nodes represent bootstrap percentages from 1000 replicates in a full heuristic search. Bar, 10 changes. 


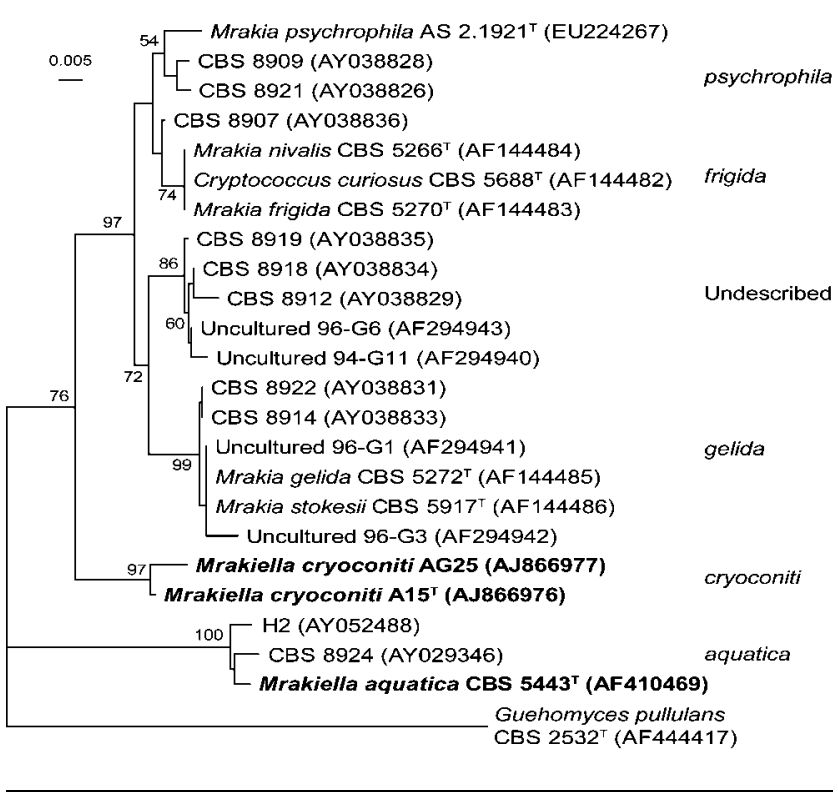

Fig. 2. Neighbour-joining analysis (PAUP 4.0b10) of GenBank sequence data of strains related to Mrakia species based on ITS rRNA gene sequence analysis. Numbers on branches represent bootstrap percentages from 1000 replicates in a full heuristic search. Unnamed CBS strains represent sequences from ThomasHall (2005); uncultured, sequences from DePriest et al. (2000); the sequence of Cryptococcus aquaticus $\mathrm{H} 2$ was reported by Birgisson et al. (2003). Guehomyces pullulans CBS $2532^{\top}$ is used as the outgroup. Bar, 0.005 substitutions per site.

(2005), whose strains are indicated by the unnamed CBS strains. Other studies include a strain from Iceland (H2; Birgisson et al., 2003) and cloned sequences from fossil lichens in Greenland (uncultured strains; DePriest et al., 2000).

As presently viewed, the Mrakia clade consists of six clusters: (i) Mrakia psychrophila from Antarctic soil (Xin \& Zhou, 2007), with two Antarctic strains (Thomas-Hall, 2005); (ii) Mrakia frigida, with the synonym Mrakia nivalis and the type strain of Cryptococcus curiosus, whose sexual state was reported by Fell \& Statzell-Tallman (1998); (iii) an undescribed species that is represented by Antarctic strains (Thomas-Hall, 2005) and two cloned sequences from Greenland lichens (DePriest et al., 2000); (iv) Mrakia gelida and strains from the Antarctic and cloned sequences from fossil lichens (DePriest et al., 2000); (v) Mrakiella cryoconiti; and (vi) Cryptococcus aquaticus (Mrakiella aquatica comb. nov.) with a strain (H2) from Iceland that has an optimal temperature for growth of $9{ }^{\circ} \mathrm{C}$ and a $T_{\max }$ of $18{ }^{\circ} \mathrm{C}$ (Birgisson et al., 2003). Cryptococcus aquaticus CBS $5443^{\mathrm{T}}$ is representative of several Antarctic strains with similar or identical ITS sequences (NCBI BLAST and Thomas-Hall, 2005). An NCBI BLAST comparison of D1/ D2 gene sequences of CBS $5443^{\mathrm{T}}$ (GenBank accession no. AF075470) with CBS 8924 (AY029345) demonstrated 9 position differences. A similar ITS comparison (Fig. 2) showed 5 differences. Mating studies between CBS $5443^{\mathrm{T}}$ and CBS 8924 and the additional Antarctic strains were negative (S. Thomas-Hall, personal communication), which suggests the presence of separate species. However, comparative phenotypic and biochemical tests must be completed prior to the formal presentation of new taxa (S. Thomas-Hall, personal communication).

This ITS analysis (Fig. 2) shows that strains $\mathrm{A}^{2} 5^{\mathrm{T}}$ and AG25 represent a separate genotype (species) within the Mrakia clade. Due to the lack of an observed sexual state, the species should not be included within Mrakia; therefore, the species should be described as the anamorphic state. The genus Cryptococcus is the traditional nomenclature selected for anamorphic species in the Tremellomycetes. However, the type species, Cryptococcus neoformans, is a member of the order Tremellales. Therefore, in our opinion, the nomenclatural designation of Cryptococcus for species within the Cystofilobasidiales is not appropriate. As previously discussed and depicted in Fig. 1, the Cystofilobasidiales represents a diverse group of anamorphic and teleomorphic genera with strong bootstrap support for these generic groups. Consequently, we believe that Mrakiella should be confined to the Mrakia clade.

As demonstrated by D1/D2 and ITS rRNA gene sequence analyses (Figs 1 and 2; Fell et al., 2000; Scorzetti et al., 2002), Cryptococcus aquaticus is an anamorphic species in the Mrakia clade. The type strain (CBS $5443^{\mathrm{T}}$ ) was isolated from a freshwater lake in Great Britain. That strain was originally described (Jones \& Sloof, 1966) with a $T_{\max }$ of $25{ }^{\circ} \mathrm{C}$; however, our own investigations demonstrated the absence of growth at $25{ }^{\circ} \mathrm{C}$ but growth at $20{ }^{\circ} \mathrm{C}$ both in liquid culture and on agar plates in different media. The absence of growth at $25^{\circ} \mathrm{C}$ is also indicated by the CBS Data Base (http://www.cbs.knaw.nl/) and Barnett et al. (2000). This discrepancy from the original strain description could be explained by culture methodology (unfortunately not indicated by Jones \& Sloof, 1966), since microbial $T_{\max }$ can be influenced by a number of factors within the culture conditions, such as medium composition or cultivation in liquid or on solid media (Bowman et al., 1998). As discussed previously, the Cryptococcus aquaticus cluster may represent several species. The relationship of this cluster and Cryptococcus aquaticus to the Mrakia clade demonstrates that Cryptococcus aquaticus should be included in the genus Mrakiella.

\section{Latin diagnosis of Mrakiella Margesin et Fell gen. nov.}

Fungi Cystofilobasidialium asexuales, affinitas cum Mrakia. Hyphae non formantur, pseudohyphae formentur. Flosculi sunt polares. Coloniae cremeae ad subfuscae in colouri. Nitratum assimilatur, materia amyloidea iodophila formatur. Reactiones $\mathrm{DBB}$ et ureasi positivae. Incrementum psychrophilicum (incrementum ad $1{ }^{\circ} \mathrm{C}$ respondet, incrementum ad $25{ }^{\circ} \mathrm{C}$ non respondet). Typus Mrakiella cryoconiti Margesin et Fell. 


\section{Description of Mrakiella Margesin \& Fell gen. nov.}

Mrakiella (Mra.ki.el'la. N.L. fem. n. Mrakiella referring to Professor E. M. Mrak).

Asexual members of the Cystofilobasidiales, which are closely related to the teleomorphic genus Mrakia. True hyphae are not produced, but pseudohyphae may be produced. Reproduction occurs by polar budding. Colonies are cream-coloured to light tan. Nitrate is assimilated, starch-like compounds are produced, DBB and urease reactions are positive. Psychrophilic growth characteristics (good growth at $1{ }^{\circ} \mathrm{C}$, absence of growth at $25^{\circ} \mathrm{C}$ ). The type species is Mrakiella cryoconiti Margesin \& Fell.

\section{Latin diagnosis of Mrakiella cryoconiti Margesin et Fell sp. nov.}

In agaro SabG et CMA post 5 dies ad $15{ }^{\circ} \mathrm{C}$, cellulae ovoideae $(3-4 \times 5-8 \mu \mathrm{m}$ in agaro SabG; $2-3 \times 3-6 \mu \mathrm{m}$ in agaro CMA). Flosculi sunt polares. In agaro CMA et SabG, coloniae cremeae in colori, rotundae, convexae et margine toto. Pseudohyphae et hyphae non formantur. Fermentatio (glucosum) nulla. Assimilat D-arabinosum, L-arabinosum, cellobiosum, D-galactosum (typus: exigue), D-glucosum, Dlactosum, maltosum, melezitosum, palatinosum, raffinosum, D-ribosum, L-sorbosum, sucrosum, trehalosum, D-xylosum, D-sorbitolum (=D-glucitolum), D-mannitolum, glycerolum, inositolum, ribitolum (=adonitolum), ethanolum, $\mathrm{N}$-acetylglucosaminum, potassium 2-ketogluconatum, potassium 5ketogluconatum, potassium gluconatum, sodium glucuronatum, succinatum, salicinum, nitratum, nitritum, L-lysinum. Non assimilat erythritolum, galactitolum (=dulcitolum), DLlactatum, methanolum, acidum laevulinicum, methyl- $\alpha-\mathrm{D}-$ glucopyranosidum, phenolum $(1 \mathrm{mM})$, cadaverinum. Thiaminum externum ad crescentiam necessarium est. Incrementum respondet in medio $50 \%$ glucosum aut ampicillino $\left(50 \mu \mathrm{g} \mathrm{ml}^{-1}\right)$. Non crescit in medio $1 \%$ acido acetico aut $0.01 \%$ cycloheximido. Materia amyloidea iodophila formatur. Reactiones ureasi, lipasi, proteasi, pectatum-lyasi, $\beta$-lactamasi, $\beta$-glucosidasi positivae sunt. Arbutinum finditur. Incrementum ad $1-20{ }^{\circ} \mathrm{C}$ respondet, ad $25{ }^{\circ} \mathrm{C}$ non respondet. Typus $\mathrm{A} 15^{\mathrm{T}}$ isolatus ex cryoconito glacialis, Stubaier Glacier, Austria, depositus in collectione zymotica Centraalbureau voor Schimmelcultures, Utrecht, Nederlandia, CBS $10834^{\mathrm{T}}\left(=\mathrm{DSM} 21094^{\mathrm{T}}\right)$.

\section{Description of Mrakiella cryoconiti Margesin \& Fell sp. nov.}

Mrakiella cryoconiti (cry.o.co.ni'ti. N.L. gen. n. cryoconiti from cryoconite, referring to glacier cryoconite, where the type strain was found).

After 5 days of growth at $15{ }^{\circ} \mathrm{C}$ on SabG agar and CMA, the cells are ovoid $(3-4 \times 5-8 \mu \mathrm{m}$ on SabG agar; $2-3 \times 3$ $6 \mu \mathrm{m}$ on CMA) (Fig. 3). Budding is polar. Colonies are creamy white on CMA and SabG agar. Colonies are round

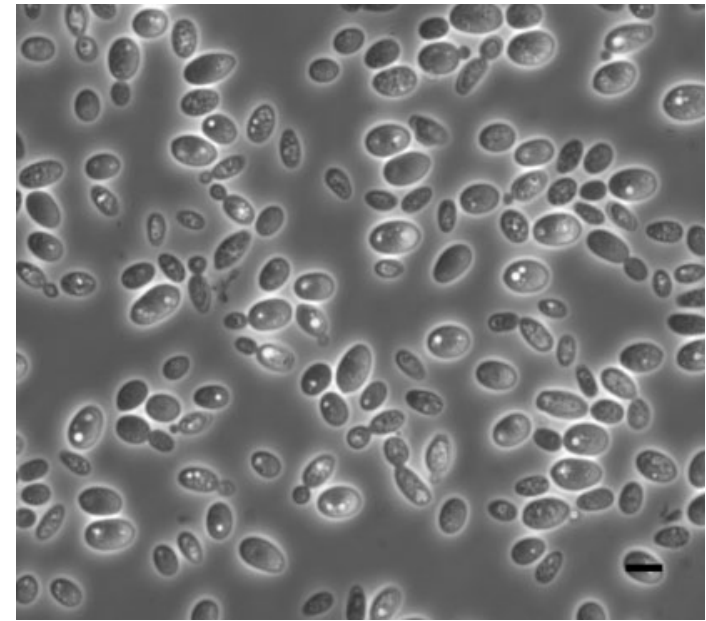

Fig. 3. Yeast cells of Mrakiella cryoconiti $\mathrm{A} 14^{\top}$ after 9 days at $15{ }^{\circ} \mathrm{C}$ in SabG broth. Bar, $5 \mu \mathrm{m}$.

and convex, with entire margins. No pseudohyphae or true hyphae are formed. Fermentation ability (glucose) is negative. The following compounds are assimilated: Darabinose, L-arabinose, cellobiose, D-galactose (type strain: weak), D-glucose, D-lactose, maltose, melezitose, palatinose, raffinose, D-ribose, L-sorbose, sucrose, trehalose, Dxylose, D-sorbitol (=D-glucitol), D-mannitol, glycerol, inositol, ribitol (=adonitol), ethanol, $\mathrm{N}$-acetylglucosamine, potassium 2-ketogluconate, potassium 5-ketogluconate, potassium gluconate, sodium glucuronate, succinate, salicin, nitrate, nitrite and L-lysine. Erythritol, galactitol (=dulcitol), methanol, DL-lactate, laevulinic acid, methyl $\alpha$-D-glucopyranoside (=methyl $\alpha$-D-glucoside), phenol $(1 \mathrm{mM})$ and cadaverine are not assimilated. Amino acids are not required for growth, but thiamine is required for growth. Growth occurs on $50 \%$ glucose agar and in presence of ampicillin $\left(50 \mu \mathrm{g} \mathrm{ml}^{-1}\right)$. No growth in the presence of $1 \%$ acetic acid or cycloheximide $(0.01 \%)$. Formation of extracellular amyloid compounds, activities of urease hydrolysis, lipase (Tween 80), protease (skimmed milk), pectate lyase, $\beta$-lactamase, $\beta$-glucosidase (hydrolysis of aesculin) and splitting of arbutin are present. Growth occurs at $1-20{ }^{\circ} \mathrm{C}$ but not at $25{ }^{\circ} \mathrm{C}$.

The type strain is $\mathrm{A} 15^{\mathrm{T}}\left(=\mathrm{CBS} 10834^{\mathrm{T}}=\mathrm{DSM} 21094^{\mathrm{T}}\right)$. Strains were isolated from alpine glacier cryoconite collected from the Stubaier glacier near Innsbruck in Tyrol, Austria $\left(\mathrm{A} 15^{\mathrm{T}}\right)$, or a sediment sample containing mud, spring water and moss, collected in the Gyda peninsula in northern Siberia (AG25).

\section{Mrakiella aquatica (Jones \& Sloof) Margesin \& Fell comb. nov.}

Basionym: Candida aquatica Jones \& Sloof. Antonie van Leeuwenhoek 32, 224, 1966. 
Synonyms: Vanrija aquatica (Jones \& Sloof) R. T. Moore (1980); Cryptococcus aquaticus (Jones \& Sloof) Rodriques de Miranda \& Weijman (Weijman et al., 1988).

Type strain: CBS 5443.

\section{ACKNOWLEDGEMENTS}

R. M. thanks A. M. Gounot for providing strain AG25 and F. Schinner for providing cryoconite samples. Research by J.W.F. was supported by National Science Foundation (USA) grant DEB 0206521. We thank H. G. Trüper for his comments on the species name.

\section{REFERENCES}

Bab'eva, I. P., Lisichkina, G. A., Reshetova, I. S. \& Danilevich, V. N. (2002). Mrakia curviuscula sp. nov.: a new psychrophilic yeast from forest substrates. Microbiology (English translation of Mikrobiologiia) 71, 449-454.

Barnett, J. A., Payne, R. W. \& Yarrow, D. (2000). Yeasts: Characteristics and Identification, 3rd edn. Cambridge: Cambridge University Press.

Birgisson, H., Delgado, O., Garcia Arroyo, L., Hatti-Kaul, R. \& Mattiasson, B. (2003). Cold-adapted yeasts as producers of coldactive polygalacturonases. Extremophiles 7, 185-193.

Bowman, J. P., Gosink, J. J., McCammon, S. A., Lewis, T. E., Nichols, D. S., Nichols, P. D., Skerrat, J. H., Staley, J. T. \& McMeekin, T. A. (1998). Colwellia demingiae sp. nov., Colwellia hornerae sp. nov., Colwellia rossensis sp. nov. and Colwellia psychrotropica sp. nov.: psychrophilic Antarctic species with the ability to synthesize

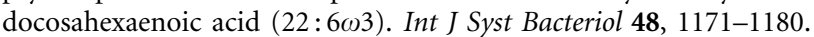

DePriest, P. T., Ivanova, N. V., Fahselt, D., Alstrup, V. \& Gargas, A. (2000). Sequences of psychrophilic fungi amplified from glacierpreserved ascolichens. Can J Bot 78, 1450-1459.

Diaz, M. R. \& Fell, J. W. (2000). Molecular analysis of ITS and IGS rDNA regions of the psychrophilic yeasts in the genus Mrakia. Antonie van Leeuwenhoek 77, 7-12.

Fell, J. W. \& Statzell-Tallman, A. (1998). The genus Mrakia. In The Yeasts, a Taxonomic Study, 4th edn, pp. 667-668. Edited by C. P. Kurtzman \& J. W. Fell. Amsterdam: Elsevier.

Fell, J. W., Roeijmans, H. \& Boekhout, T. (1999). Cystofilobasidiales, a new order of basidiomycetous yeasts. Int J Syst Bacteriol 49, 907-913.

Fell, J. W., Boekhout, T., Fonseca, A., Scorzetti, G. \& StatzellTallman, A. (2000). Biodiversity and systematics of basidiomycetous yeasts as determined by large subunit rD1/D2 domain sequence analysis. Int J Syst Evol Microbiol 50, 1351-1371.

Fell, J. W., Boekhout, T., Fonseca, A. \& Sampaio, J. P. (2001). Basidiomycetous yeasts. In The Mycota. Systematics and Evolution, vol. VII, part B, pp. 1-37. Edited by K. Esser \& P. A. Lemke. Berlin: Springer.

Fell, J. W., Scorzetti, G., Statzell-Tallman, A. \& Boundy-Mills, K (2007). Molecular diversity and intragenomic variability in Xanthophyllomyces: the origin of Phaffia rhodozyma? FEMS Yeast Res 7, 1399-1408.

Felsenstein, J. (1985). Confidence limits on phylogenies: an approach using the bootstrap. Evolution 39, 783-791.

Gounot, A. M. (2001). Ecology of psychrophilic and psychrotrophic microorganisms in cold and frozen soils. In Permafrost Response on Economic Development, Environmental Security and Natural Resources, pp. 543-551. Edited by R. Paepe \& V. P. Melnikov. Dordrecht: Kluwer Academic.
Johnson, E. A. (2003). Phaffia rhodozyma: colorful odyssey. Int Microbiol 6, 169-174.

Jones, E. B. G. \& Sloof, W. Ch. (1966). Candida aquatica sp. n. isolated from water scums. Antonie van Leeuwenhoek 32, 223-228.

Kurtzman, C. P. \& Fell, J. W. (editors) (1998). The Yeasts: a Taxonomic Study, 4th edn. Amsterdam: Elsevier.

Margesin, R., Zacke, G. \& Schinner, F. (2002). Characterization of heterotrophic microorganisms in alpine glacier cryoconite. Arct Antarct Alp Res 34, 88-93.

Margesin, R., Fauster, V. \& Fonteyne, P. A. (2005). Characterization of cold-active pectate lyases from psychrophilic Mrakia frigida. Lett Appl Microbiol 40, 453-459.

Margesin, R., Schinner, F., Marx, J. C. \& Gerday, C. (editors) (2008). Psychrophiles: from Biodiversity to Biotechnology. Berlin \& Heidelberg: Springer.

Moreira, S. R., Schwan, R. F., Pinhiero de Carvalho, E. \& Wheals, A. E. (2001). Isolation and identification of yeasts and filamentous fungi from yoghurts in Brazil. Braz J Microbiol 32, 117-122.

Morita, R. Y. (1975). Psychrophilic bacteria. Bacteriol Rev 39, 144-167.

Nakagawa, T., Nagaoka, T., Taniguchi, S., Miyahii, T. \& Tomizuka, N. (2004). Isolation and characterization of psychrophilic yeasts producing cold-adapted pectinolytic enzymes. Lett Appl Microbiol 38, 383-387.

O'Donnell, K., Cigelnik, E., Weber, N. S. \& Trappe, J. M. (1997). Phylogenetic relationships among ascomycetous truffles and the true and false morels inferred from $18 \mathrm{~S}$ and $28 \mathrm{~S}$ rDNA sequence analysis. Mycologia 89, 48-65.

Panikov, N. S. \& Sizova, M. V. (2007). Growth kinetics of microorganisms isolated from Alaskan soil and permafrost in solid media frozen down to $-35{ }^{\circ} \mathrm{C}$. FEMS Microbiol Ecol 59, 500-512.

Ramírez, C. \& González, A. (1984). Two new filamentous, nonfermenting Candida and a new Schizoblastosporion isolated from decayed wood in the evergreen rainy Valdivian forest of southern Chile. Mycopathologia 88, 165-171.

Rodrigues de Miranda, L. (1984). Genus 5. Cryptococcus Kützing emend. Phaff et Spencer. In The Yeasts, a Taxonomic Study, 3rd edn, pp. 845-872. Edited by N. J. V. Kreger-van Rij. Amsterdam: Elsevier.

Sampaio, J. P. (2004). Diversity, phylogeny and classification of basidiomycetous yeasts. In Frontiers in Basidiomycote Mycology, pp. 49-80. Edited by R. Agerer, M. Piepenbring \& P. Blanz. Eching, Germany: IHW-Verlag.

Scorzetti, G., Fell, J. W., Fonseca, A. \& Statzell-Tallman, A. (2002). Systematics of basidiomycetous yeasts: a comparison of large subunit D1D2 and internal transcribed spacer rDNA regions. FEMS Yeast Res 2, 495-517.

Swofford, D. L. (2001). PAUP*: Phylogenetic analysis using parsimony (and other methods). Sunderland, MA: Sinauer Associates.

Thomas-Hall, S. (2005). Part A. Physiological and biochemical analysis of novel species from Antarctica. In Phylogenetic studies of fungi, pp. 1-178. PhD thesis, University of New England, Armidale, Australia.

Turchetti, B., Buzzini, P., Goretti, M., Branda, E., Diolaiuti, G., D'Agata, C., Smiraglia, C. \& Vaughan-Martini, A. (2008). Psychrophilic yeasts in glacial environments of alpine glaciers. FEMS Microbiol Ecol 63, 73-83.

Weber, R. W. S., Becerra, J., Silva, M. J. \& Davoli, P. (2008). An unusual Xanthophyllomyces strain from leaves of Eucalyptus globulus in Chile. Mycol Res 112, 861-867.

Xin, M. X. \& Zhou, P. J. (2007). Mrakia psychrophila sp. nov., a new species isolated from Antarctic soil. J Zhejiang Univ Sci B 8, 260-265. 